\title{
嵩高紙一日本製紙の挑戦*
}

日本製紙株式会社 技術研究所 越 智隆

\section{Challenge to the Development of Bulky Paper in NPI}

Takashi Ochi

Nippon Paper Industries Co., Ltd.

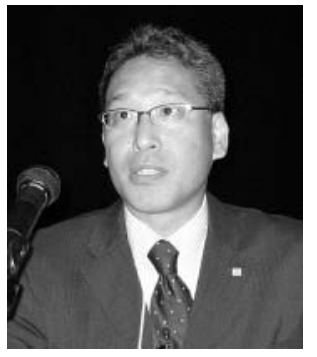

Bulky paper is getting popular in the past ten years. If the thickness of paper is the same, the weight of bulky paper is lighter than conventional paper. This means that bulky paper is environmentally friendly because of the lower amount of pulps and other energy consumption, and is human friendly as well. Nippon Paper Industries Co., Ltd. (NPI) has been developing and producing bulky paper ranging from non-coated paper to coated grade by new technologies. These new bulking technologies are based on fillers and chemicals. These materials were not used for bulking paper in the past. NPI has challenged and succeeded to use these new technologies. Precipitated calcium carbonate (PCC) which has scalenohedral shape and appropriately controlled particle size is favorable for bulky paper. Those PCCs have been producing at mill-site plants of NPI. Chemicals for bulky paper (bulking agents) work as blocking hydrogen bonds of fibers and so cause the decrease of strength of paper. For this reason, paper makers have hesitated to use these chemicals. However, NPI has had conquered problems to use the bulking agents. With well designed filler and bulking agent and other novel technologies, up to $30 \%$ lighter wood free book grade can be obtained.

分類 $: \mathrm{S}_{1}$ 紙の性質一般， $\mathrm{S}_{4}$ 非塗工印刷用紙， $\mathrm{S}_{5}$ 塗工印刷用紙（微塗工印刷用紙を含む）

\section{1. はじめに}

\section{1 印刷用紙の需要動向}

国内における紙・板紙市場（図 1）は約 31 百万トンであ り，その約 6 割は紙が占める ${ }^{1)}$ 。新聞用紙が 3.7 百万トンで あるが，当社はこの新聞用紙については中性抄造化し，高品 質新聞として市場に大きなインパクトを与えている。一方, 紙需要で最も多い 9.7 百万トンの市場（紙市場の約 5 割）を 持つのが印刷・出版用紙である。しかしながらこの分野も市 場が縮小傾向にあり，厳しい環境下にある。

図 2 に書籍, 雑誌の販売額推移を示した。1996 年をピー クに所謂, 紙の本の販売高も減少傾向にある。これは情報入 手におけるインターネットなど他メディアの進展, 社会環境 変化（活字離れ，携帯電話の普及等）によるところが大きい。 印刷・出版用紙も当然その影響を受け，また，紙メディアで の広告の減少による冊子当りのページ数の減少といった影響 もある。そのような厳しい環境下において，当社がここ数年，

*平成 18 年度年次大会講演（講演 No. A 3)
開発・上市してきた嵩高紙は販売量が大きく増えている。

\section{2 日本製紙の嵩高軽量紙}

嵩高紙とは, 軽くても紙厚のある紙, 即ち同じ紙厚では従 来の紙より軽く出来る点に大きな特徴がある。当然, 単純に 坪量を減らせば紙厚や, 不透明度などの品質も低下するので, これを軽量化しても紙厚や不透明度などの品質を維持, 向上 させる技術革新が必要であり，これら技術により最近の嵩高 軽量紙の抄造が可能となった。紙の峪高化により, 例えば同 じページ数でも軽い本が出来 (写真 1), 持ち運びに便利で ある。あるいは同じ重さではより厚い立派な本が出来るとい ったメリットがある。

また，軽いということは，原料パルプの使用量が少なくて 済み（図 3), 木材資源の節約にも繋がり，運搬時のエネル ギー消費低減，それに伴う炭酸ガス排出量も少なくて済むな ど，環境や省資源の観点でもメリットが大きい。このため， 当社としては単に嵩高軽量紙という位置づけではなく, 今後, 一層重要となってくる環境保全への取組みに貢献することが 出来る省資源紙との位置づけで積極的に開発を進めている。

品質, 環境・資源面の他にも同じ紙厚であればより軽い紙 

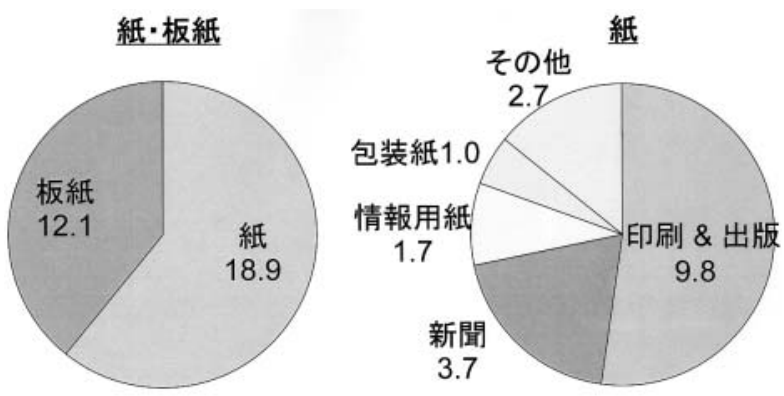

単位: 百万トン /年

紙・板紙統計年報（日本製紙連合会）デー夕

図 1 日本の紙・板紙販売量（2005）

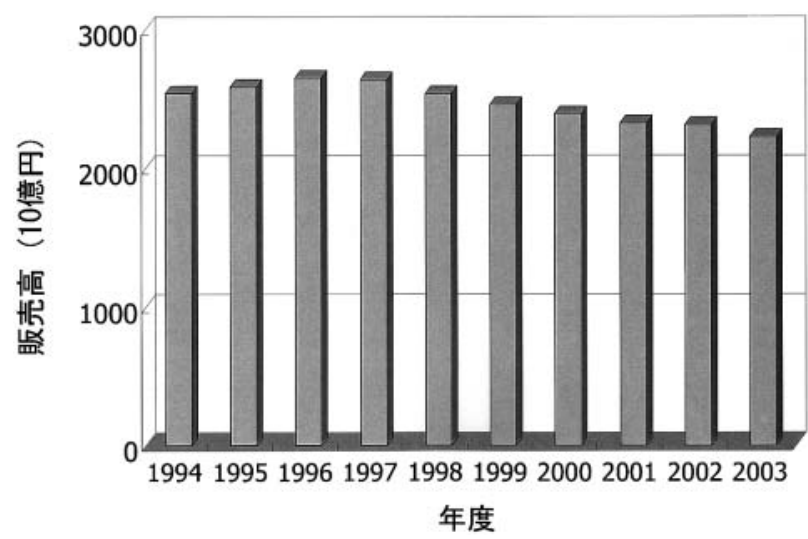

図 2 書籍, 雑誌類販売額推移

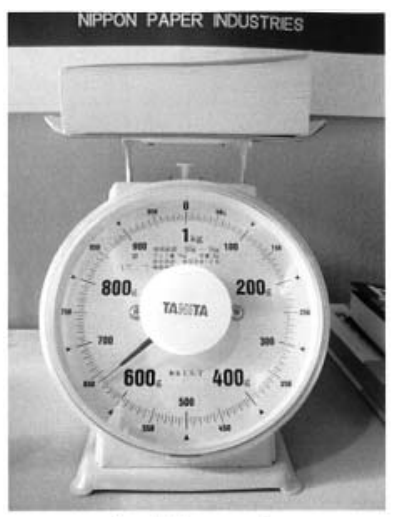

一般紙(640g)

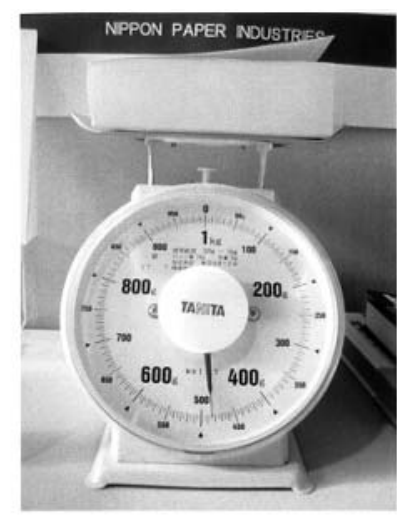

嵩高軽量紙 $(485 \mathrm{~g})$
写真 1 一般紙と軽量嵩高紙の重さ比較 (A 5 判，200 ページ，同じ厚さ)

の選択が可能となるため, 重量単位で取引される紙取引に於 いては，顧客サイドの用紙購入コスト削減の可能性もある。 このように品質や製品競争力, また環境面でも大いに貢献で きる製品であり，積極的に開発・上市を進めており，最近で は非塗工紙から塗工紙，キャスト紙までの嵩高軽量紙を当社 製品としてラインナップしている（図4）。

\section{2. 嵩高軽量紙の製造技術}

紙を嵩高化（低密度化）する場合，中質系の紙では当然，

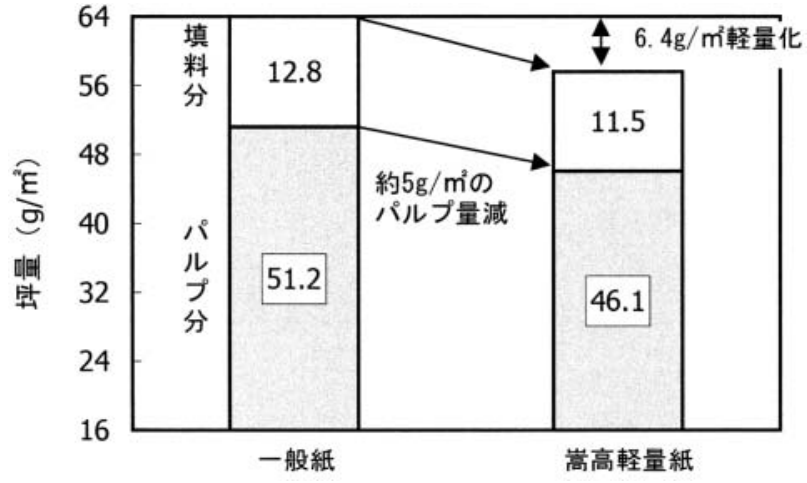

図 $310 \%$ 嵩高軽量化時の原料削減（同一紙厚）

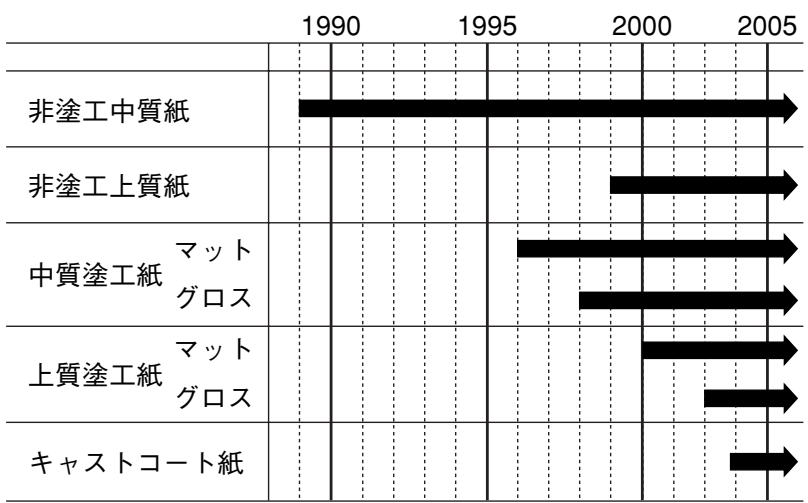

図 4 嵩高軽量紙製品の上市状況

嵩高な機械パルプの配合が可能であり，当社でも適正な機械 パルプの選択，配合を実施している。しかしながら，上質系 の紙では難しい。

図 5 にはLBKP 100\%の手抄き紙を基準にBCTMPを配 合していった場合の嵩向上率と紫外線照射による退色試験実 施後の白色度変化率を示す。嵪高な BCTMP 配合で嵩は向 上するが，一方で経時での白色度低下（退色）は避けられず， この処方では上質系の紙の嵩高化は難しい。また，抄紙機の プレスやカレンダー処理線圧の低減なども実施されるが，平 滑性が低下する問題もあり，新たな技術が必要であった。

\section{1 填料}

填料を配合すると紙は締まる（嵩を下げる）と考えるのが 一般的であった。図 6 には各種填料を配合していった場合の 手抄き紙の密度変化を示した。カオリン, タルクといった従 来の酸性抄造で用いられた填料では密度上昇し, 即ち嵩が出 ない紙となっている。一方，軽質炭酸カルシウム（PCC）は 密度を大きく上げることはなく, また PCC の中でも密度へ の影響に違いがある。逆に密度を下げるものもある。眓中の PCC 3 は紙中への $10 \%$ 程度までの配合では密度を下げる(嵩 高い) 効果がある。

これは軽カルの形態，粒子径が影響していると考えている。 嵩を出し易い軽カルは紡錘形が凝集したような形態を持ち (写真 2)，填料自体に空隙を持つ。更に光学品質とのバラン スの中で粒子径を大きくすることで，紙に配合した場合に嵩 が出易いと考えている。嵩高軽量紙のためには従来あまりな い考え方であるが填料でも嵩高化を行なう必要がある。 


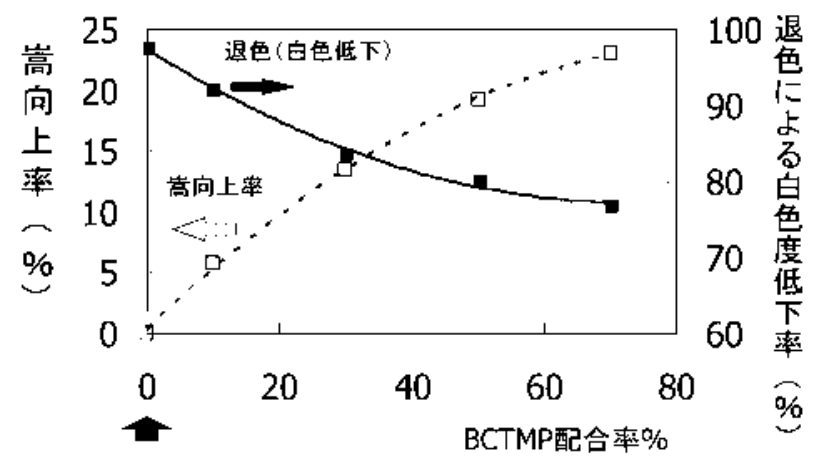

LBKP $100 \%$

図 5 機械パルプ配合時の紙質（BCTMP 配合）

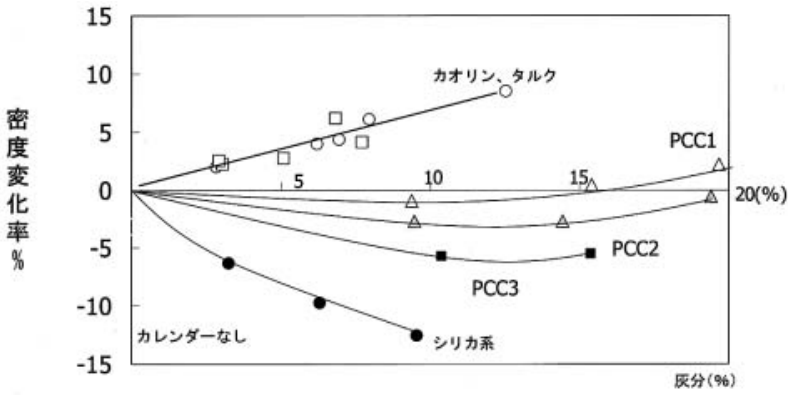

図 6 填料配合時の手抄き紙密度
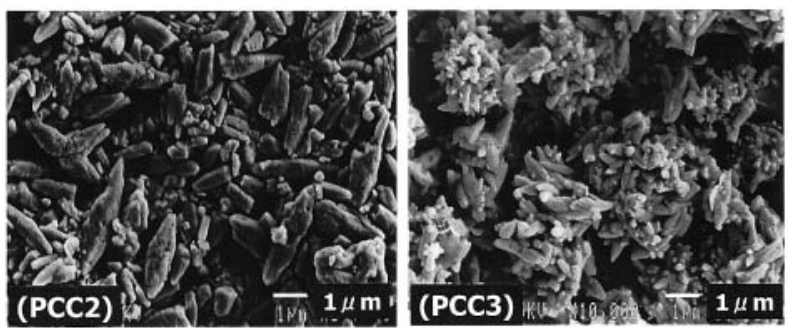

紡鍾状の軽カル

凝集形態の軽カル

写真 2 PCC 電顕写真

炭酸カルシウムは日本に豊富に存在する石灰石を原料とし, 嵩への影響の他にカオリンやタルクといった従来の酸性抄造 で使用してきた填料より白色度も高い。その中でも，適正な 形態の PCC は用紙を高高化し，更に光学品質も高い。この ため，当社は PCCを全面的に使用すべく，中性抄造に転換 している。

またその内添用 PCC については当社における数多くの工 場内で自製を開始している（図 7）。形態，粒子径を適正に 制御して軽量嵩高化に寄与すると共に，PCC 製造時には製 紙工場で排出される炭酸ガスを有効利用できるので環境負荷 も低減出来るメリットもある。その他，必要に応じてより用 紙を嵩高に出来る填料など適宜使用し, 従来の常識とは逆に 填料による嵩高軽量化を図っている。

\section{2 嵩高化薬品}

中質紙は嵩高なパルプの配合は可能であり，このため上質 紙に比較し密度（嵩が出やすい）が低く，嵩高な填料を配合 しても更なる嵩高化は難しい。そこで開発されてきたのが繊

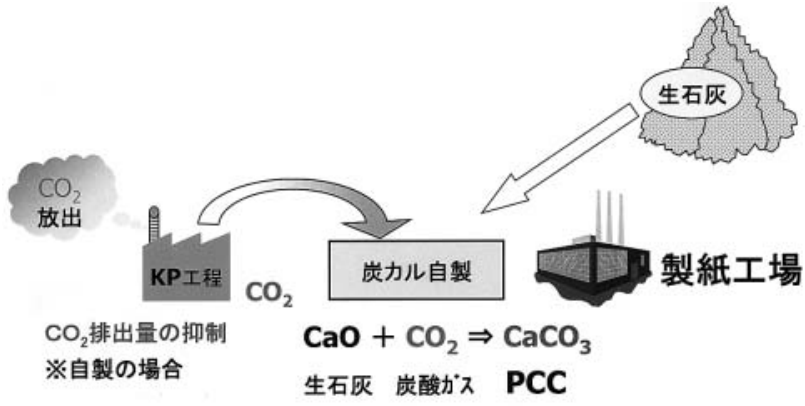

\section{·適正な形態、粒径で自製 $\rightarrow$ 嵩高軽量へ \\ ·排出される工場の $\mathrm{CO}_{2}$ を有効利用 $\rightarrow$ 環境負荷低隇}

図 7 製紙工場内での PCC 自製

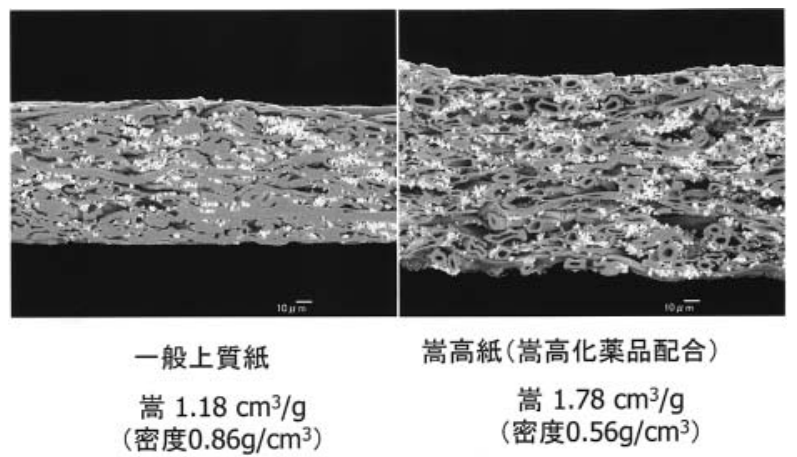

写真 3 嵩高軽量紙の断面

維間結合を阻害することで繊維間の結合距離を広くして高を 出す薬品である。

写真 3 に嵩高化薬品添加前後の紙の断面電子顕微鏡写真を 示す。同じ坪量であるが，䋊維間の間隔が広く空間が出来て おり，紙厚が大きく向上し，嵩高になっていることが分かる。 一方で，紙厚を同じにすれば，坪量を下げることが可能であ り，軽量で木材パルプ使用量の少ない紙を抄造出来る。

このような繊維間結合阻害薬品の使用に際しては, 強度低 下やウェットエンド（歩留り低下）等に大きな影響があり， この様な薬品による紙の嵩高軽量化は従来，進んでいなかっ た。表 1 に嵩高化薬品を添加した場合の密度と裂断長の変化 を示すが，添加により密度の低下すなわち嵩は出るが，裂断 長は大幅に低下する。

実際に紙を抄造する側としてはこのような薬品の添加は断 紙を助長する要因であり, 使用は通常難しいと判断する。こ れが従来, 繊維間結合を阻害する高高化薬品のような薬品が 使用されなかった一因である。紙力低下に対しては, 内添紙 力剤添加を考えると, 紙力剤は繊維間結合を増やすので密度 は逆に上がってしまい，嵩高化には反する。そこで䋐維間結 合点数を出来るだけ増やさず，密度を上げないで強度を向上 させる紙力剤の選択が重要である。最近ではこのような紙力 羭の研究も行われて来ている ${ }^{2}$ 。

また，嵩高化薬品の添加で紙の破断強度は大幅に低下する が，この薬品の添加により力が加わった際の紙は伸び易くな る。このため破断するまでの外力に対しては，紙が伸びるこ とで応力集中が避けられ，抄紙機や印刷機上で比較的断紙す 
表 1 嵩高化薬品添加時の密度と強度 (手抄き紙)

\begin{tabular}{l|c|c|c|c}
\hline \multicolumn{1}{c|}{ 項目 } & 単位 & 薬品なし & 薬品 1 & 薬品 2 \\
\hline 密度 & $\mathrm{g} / \mathrm{cm}^{3}$ & 0.64 & 0.58 & 0.59 \\
\hline 密度低下 & $\%$ & - & 9.4 & 8.0 \\
\hline 裂断長 & $\mathrm{km}$ & 3.78 & 2.35 & 2.80 \\
\hline 強度低下 & $\%$ & - & 38.0 & 25.9 \\
\hline
\end{tabular}

ることが少ないことがわかってきた。その他，嵩高化薬品を 使用するうえでの諸問題も解決しながらこの軽量化技術を推 進している。

\section{3 嵩高原紙への塗工}

当社は嵩高軽量紙を非塗工紙から塗工紙まで展開している。 塗工紙の場合，原紙を嵪高にすると塗工の際に塗料が原紙層 へ浸透しやすく，紙表面の被覆性が低下し，塗工紙として同 じ光沢度にカレンダーで調整するには，被覆性が悪くなった 分カレンダー処理線圧が高くなるため, 結局密度が変わらな い場合がある。単純な原紙嵪高化が峪高軽量塗工紙に繋がら ない（表 2）。

このため低密度（嵩高）原紙に被覆性よく塗工する技術が 重要となる（図 8）。低密度な原紙に塗工する際には塗工顔 料としては嵪高な塗工層を形成し易い粒径分布がシャープな 顔料が望まれる。このような顔料を使用することで，同じ塗 工量でも原紙被覆性が良くなる。このため，低密度な嵩高原 紙への塗工でも原紙表面を被覆し易い。また，カレンダー処 理でも出来るだけ線圧を高くしないことが重要であり, 設備 面でも例えば高温ソフトニップカレンダーが有利である。

このように塗工紙の嵩高軽量化には単純に原紙を嵩高くす るだけでは難しく，塗工顔料，塗料設計，カレンダー設備な ど各種の技術投入が必要である。これら技術を総合していく ことが高い品質をもつ嵩高軽量塗工紙の製造を可能とする。

\section{3. ま と}

嵩高軽量紙について, 当社は品質や製品競争力, また環境 面でも大いに貢献できる重要な製品と捉えている。このため パルプ, 填料, 顔料などの材料, また嵩高化薬品や紙力向上 剤などの開発，採用を積極的に行なってきた。更に抄造技術， 塗工技術開発も積極的に行い，またそれに対応すべく設備面 の改善, 新規設備導入など全社挙げて取り組んでいる。

この結果, 例えば図 9 に示すように, 当社の上質書籍用紙 ランイナップの中では, 一般品から高高軽量紙まで $30 \%$ 嵩 が異なる品種が製造可能であり, 大幅な軽量化を達成してい る。一方，塗工紙においても同様にマットからグロス調塗工 紙まで，嵩高軽量化製品をラインナップしている（図 10）。

今後も, 当社の製品作りのコンセプトにおいては環境への 影響含めて高高軽量化が重要と考えており, 今後も更に製紙 機械, 資材, 薬品等の各メーカーのご協力を得ながら製品開 発を進めて行きたいと考えている。
表 2 嵩高原紙への塗工

\begin{tabular}{|c|c|c|c|}
\hline 試料 & & (1) & (2) \\
\hline 原紙密度 & $\mathrm{g} / \mathrm{cm}^{3}$ & 0.59 & 0.55 \\
\hline \multicolumn{4}{|l|}{ 塗工紙密度 } \\
\hline カレンダーなし & $\mathrm{g} / \mathrm{cm}^{3}$ & 0.77 & 0.73 \\
\hline \multicolumn{2}{|c|}{ カレンダー処理（白紙光沢 45\%） } & 基準 & 線圧 25\% 増 \\
\hline カレンダー処理後 & $\mathrm{g} / \mathrm{cm}^{3}$ & 1.07 & 1.07 \\
\hline
\end{tabular}

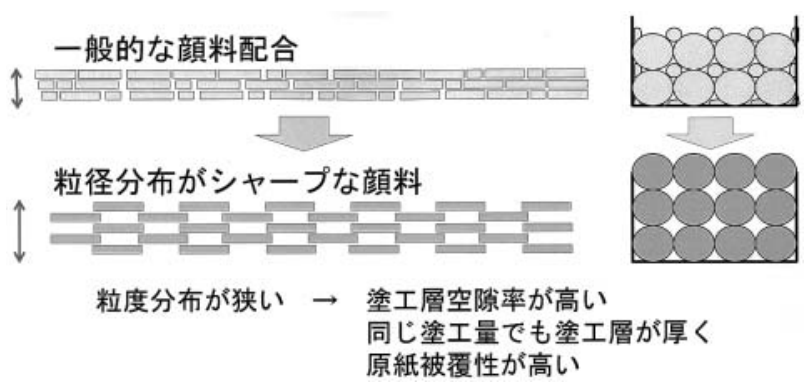

図 8 塗工技術による嵩高化（塗工顔料）

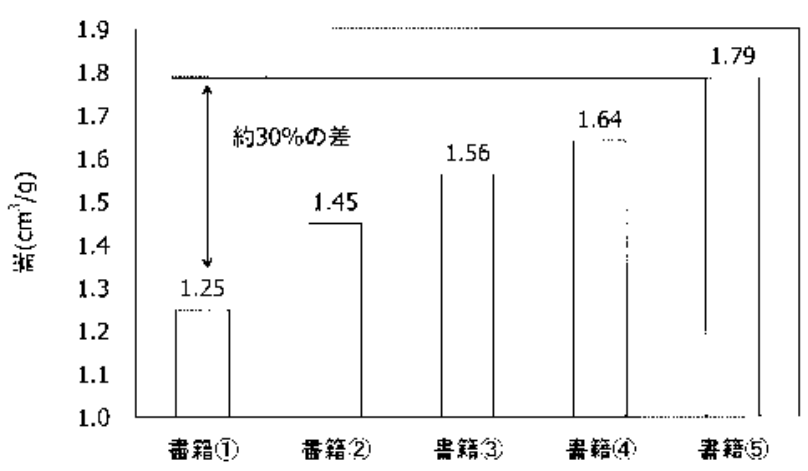

図 9 上質書籍用紙の峪高軽量化

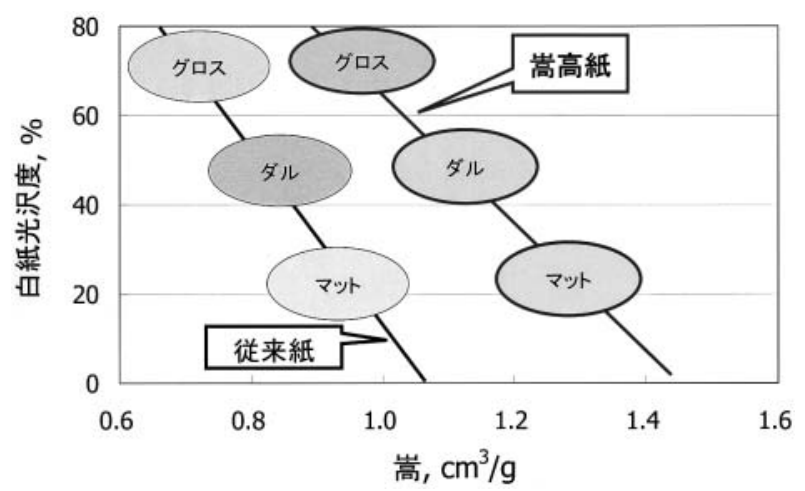

図 10 従来紙と嵩高紙比較（塗工紙）

References

1) Japan Paper Association : KAMI - ITAGAMI TOUKEINENPOU (2005)

2) N. Sone et al : JAPAN TAPPI J.59（9）60（2005） 